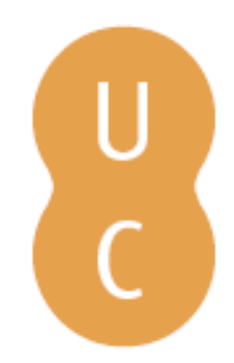

\title{
pombalina
}

\section{Predictive distribution modeling of forest fire in pine zone of Uttarakhand Himalayas of India}

\begin{tabular}{|c|c|}
\hline Autor(es): & $\begin{array}{l}\text { Verma, Amit Kumar; Kaliyathan, Namitha Nhandadiyil; Bisht, N S; } \\
\text { Nautiyal, Raman; Sharma, S D }\end{array}$ \\
\hline Publicado por: & Imprensa da Universidade de Coimbra \\
\hline $\begin{array}{l}\text { URL } \\
\text { persistente: }\end{array}$ & URI:http://hdl.handle.net/10316.2/44637 \\
\hline DOI: & DOI:https://doi.org/10.14195/978-989-26-16-506_120 \\
\hline Accessed: & 26-Apr-2023 15:24:48 \\
\hline
\end{tabular}

A navegação consulta e descarregamento dos títulos inseridos nas Bibliotecas Digitais UC Digitalis, UC Pombalina e UC Impactum, pressupõem a aceitação plena e sem reservas dos Termos e Condições de Uso destas Bibliotecas Digitais, disponíveis em https://digitalis.uc.pt/pt-pt/termos.

Conforme exposto nos referidos Termos e Condições de Uso, o descarregamento de títulos de acesso restrito requer uma licença válida de autorização devendo o utilizador aceder ao(s) documento(s) a partir de um endereço de IP da instituição detentora da supramencionada licença.

Ao utilizador é apenas permitido o descarregamento para uso pessoal, pelo que o emprego do(s) título(s) descarregado(s) para outro fim, designadamente comercial, carece de autorização do respetivo autor ou editor da obra.

Na medida em que todas as obras da UC Digitalis se encontram protegidas pelo Código do Direito de Autor e Direitos Conexos e demais legislação aplicável, toda a cópia, parcial ou total, deste documento, nos casos em que é legalmente admitida, deverá conter ou fazer-se acompanhar por este aviso.

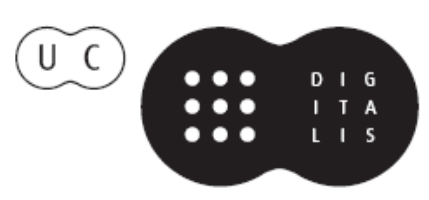




\section{ADVANCES IN}

\section{FOREST FIRE RESEARCH}

\section{8}

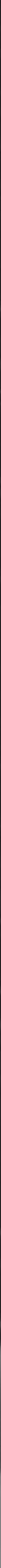




\title{
Predictive distribution modeling of forest fire in pine zone of Uttarakhand Himalayas of India
}

\author{
Amit Kumar Verma ${ }^{1}$; Namitha Nhandadiyil Kaliyathan $^{1}$; N S Bisht ${ }^{2}$, Raman Nautiyal $^{2}$, S D \\ Sharma ${ }^{2}$ \\ ${ }^{1}$ Forest Research Institute, P.O. New Forest, Dehradun, India. \{amitvermafri@gmail.com*, \\ namithafri@gmail.com\} \\ ${ }^{2}$ Indian Council of Forestry Research \& Education, P.O. New Forest, Dehradun, India, \\ \{bishtnsifs@yahoo.com,nautiyal.raman@gmail.com,sharmasatinder95@gmail.com\}
}

\begin{abstract}
Periodic forest fire in the Pine zone of Indian Himalayas has been portrayed as the great destroyer of forests. The coniferous forests in the Himalayan region, notably Pinus roxburghii stands are highly prone to fire. The lack of proper forest fire monitoring system in Pine zone is a major management issue needs attention for the long term viability. Hence the present study was attempted using Maximum Entropy (MaxEnt) method to predict the potential areas under fire across the Pine zone and to identify key variables associated with fire occurrence. A total of $n=529$ spatiotemporally independent fire incidence locations were used after auto-correlation testing. Bioclimatic environmental variables were used along with other anthropogenic, topographic, Forest type/canopy density variables. Spatial multi-collinearity of variables was tested where the variables with $\mathrm{r}>0.7$ were dropped from the analysis. The accuracy of the model was assessed using the area under the curve (AUC) and to assess the variables importance jackknife procedure was adopted. Hence, 100 model predictions were averaged to produce a probability map. The map was classified into four categories based on the probability value viz., Very highly, highly, moderately and least susceptible to fire. The results showed that the forest areas having moderate canopy density and near to village is highly affected by fire. The areas identified as very highly and highly susceptible to fire can be used for preparatory planning for management of forest fire in Pine Zone of Uttarakhand Himalayas.
\end{abstract}

Keywords: Pine Zone, MaxEnt, Forest Fire, MODIS, Modeling, Himalayas

\section{Introduction}

Pines are natives of tropics as well as the temperate climates. They are found abundantly in the Himalayas (Gamble, 1875; Craw, 1875). The major problem associated with the pine forest is that the area becomes highly vulnerable to fire due to the presence of pine needles in very large amounts. Needles are fine fuels that ignite and spread flames faster than coarse woody fuels and represent an important portion of the total fuel consumption in forest fires. It is not the thick bark but exposed resin ducts that make the pine trees prone to fire. In the Chir forests, the resin channels increase the height of the flames to about $4 \mathrm{~m}$ from where the crowns of the small poles, bigger poles and then bigger trees, in turn, catch fire thus enabling the fire to rise vertically upwards. In the Central Himalayas, particularly Uttarakhand, frequent man made fires are an integral part of the pine forest especially in P. roxburghii (Chir pine) forest between $800 \mathrm{~m}$ and $2000 \mathrm{~m}$ altitude. P. roxburghii forests encompass approximately $39,416.38$ ha or $16.15 \%$ of the total forest area of Uttarakhand. A massive forest fire in 1995 engulfed 5,948.88 ha of valuable forest area through 2,272 forest fire incidents in the state, which resulted in the loss of crores of rupees and created various long-lasting ecological consequences (Dhaundiyal and Gupta, 2014).

The major constraint in forest fire management is the lack of scientific study on identification of fire hazard areas across the country. The information about peak fire season, factors associated with fire occurrence and the areas where forest fire are likely to occur is lacking. Further, the comprehensive 
information needed to relate the fire susceptibility with habitation, road network, drainage network, distance to fire station, forest composition and density, slope, aspect, altitude, fuel type, temperature, precipitation etc. is also lacking. In Uttarakhand, the topography is highly undulating and it is difficult to control the forest fire in time. During summer, forest fires are common in these areas as pine needles, which keep falling off the trees from the middle of March till the onset of the rains in July, are highly inflammable. Fire prediction modeling and risk assessment are important tools to predict, and design measures to minimize, both direct and indirect losses due to fire. Verma et al., (2013) developed a forest fire risk zone map of Raipur Range of Mussoorie Forest Division in Uttarakhand using remote sensing and GIS. Verma and Kumar (2015) developed a Fire Hazard Map of Rajaji National Park, Uttarakhand by using multi source data comprising of cartographic documents, satellite imageries and statistical information with a combination of remote sensing and GIS data. Verma (2016) used the Maximum Entropy (MaxEnt) ecological niche modeling framework to predict the potential areas under fire across the Lansdowne Corridor of Lesser Himalayas and identified key environmental variables associated with fire occurrence. Hence similar model i.e. MaxEnt ecological niche modeling framework was used to predict the potential areas under fire across the Pine Zone and to identify the key environmental variables associated with fire occurrence.

\section{Materials and Methods}

\subsection{Study area}

The present study was conducted in Uttarakhand Himalayas of India (Figure 1). It lies on the southern slope of the Himalayan range, located between $28^{\circ} 44^{\prime}$ to $31^{\circ} 28^{\prime} \mathrm{N}$ Latitude and $77^{\circ} 35^{\prime}$ to $81^{\circ} 01^{\prime}$ E Longitude and spread over an area of $53,483 \mathrm{~km}^{2}$. Topographically, Uttarakhand can be divided into three zones namely the Himalayas, the Siwaliks and the Terai region. The terrain and topography of the State is largely hilly with large areas under snow cover and steep slopes. Major portion of the State is mountainous and these mountains (Himalayas) are one of the youngest mountain systems of the World, hence ecologically very fragile and relatively much more susceptible to earthquakes and landslides (http://sbb.uk.gov.in/pages/display/93-about-uttarakhand).

In the present study two Pine species viz., Pinus roxburghii (Chir pine) and Pinus wallichiana (blue pine) have been considered for Pine zone in Uttarakhand. According to Troup (1921), Chir pine occurs from $457 \mathrm{~m}$ to 2,286 $\mathrm{m}$ and blue pine occurs from 1,219 $\mathrm{m}$ to 3,658 $\mathrm{m}$ in Himalayas.

\subsection{Fire occurrence data}

The fire data for the period of year 2001-2016 were downloaded from https://firms.modaps.eosdis.nasa.gov in the form of shape file as point feature. However for the present study only 529 spatiotemporally independent fire incidences were used for model building. The spatiotemporally auto-correlated locations were removed after testing using Software Program DivaGIS (Hijmans et al., 2002; DIVA GIS version 2). Only one location per $1 \mathrm{~km}$ grid cell if $>1$ observation was used by clustered in a grid (i.e., to avoid autocorrelation with low sample size; Phillips et al., 2006; Pearson et al., 2007).

\subsection{Environmental variables}

The environmental and bioclimatic environmental variables were obtained from WorldClim database (Version 1.4, http://www.worldclim.org/bioclim.htm; Hijmans et al. 2005). These metrics are derived from monthly temperature and rainfall climatology and represent biologically meaningful variables for characterizing a species range. We used 19 environmental variables (11 variables for temperature, 8 for precipitation variables, expressing spatial variations in annual means, seasonality and extreme or limiting climatic factors). Forest Type layer was generated from Landsat- 8 satellite 
data by using supervised classification approach in which 30 training sets were taken from Google earth as ground control points.

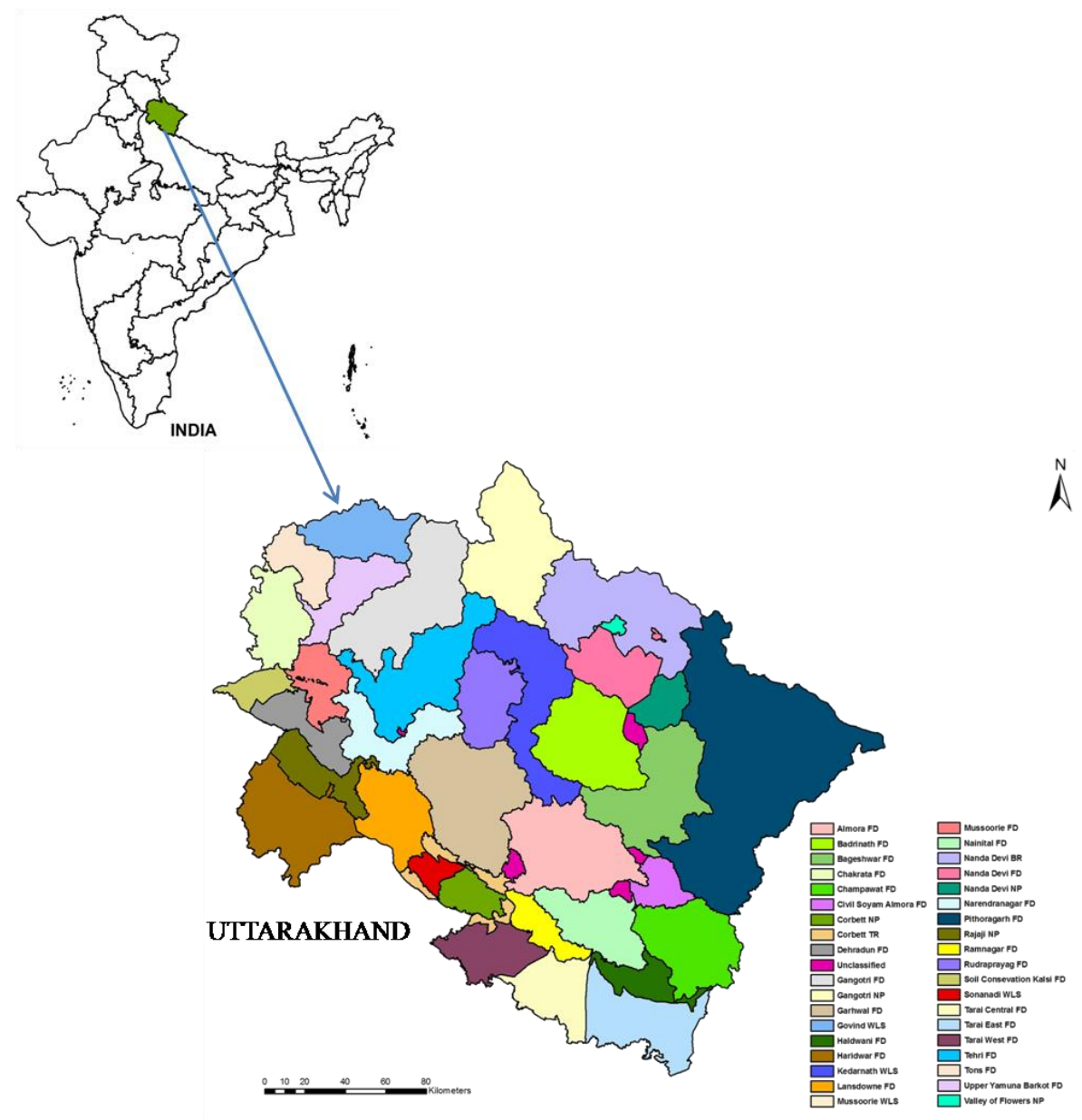

Figure 1 - Location map of the study area

Based on the field visit the study area was classified into 4 classes (table 1). Forest cover map was generated using unsupervised classification approach was used for Vegetation Density Mapping using ERDAS imagine 2013 software. The study area was classified into 50 spectral classes using unsupervised image classification approach. Eventually the Vegetation of study area was stratified into four major types on the basis of density (table 1) as per the fundamental criteria of Forest Survey of India (FSI, 2013). Slope, Aspect and Elevation map was generated from CARTOSAT 30m DEM using boundary vector layer with the help of Arc map 10.1. Road Network, Drainage Network were digitized from Survey of India Toposheet at 1:50,000 scale with the help of Arc map 10.1 software. GPS location of Habitation and Forest watch station was collected from field visits. Initially 19 'bioclimatic' variables were considered from WorldClim database. A subset of Bioclim 30m resolution of study area was clipped using boundary vector layer in Arc map 10.1.

The ENM Tools version 1.3 (Warren et al. 2010) was used to test multi co-linearity between 31 predictor variables. The criteria adopted to predict multi-collinearity between the variables was Pearson Correlation Coefficients ( $r$ ). On the basis of $r$ value we can determine whether two different variables will have distinct spatial effect on the distribution of the species or not. Henceforth the variables with $r>0.7$ i.e. variable showing more than $70 \%$ correlation were not used in analysis and model building. These variables were found to be correlated and hence only those variable were used that were found to be spatially distinct in this study. 
Table 1 - Predictor variables tested for prediction modeling of fire in Pine zone

\begin{tabular}{|c|c|c|c|c|c|}
\hline \multicolumn{3}{|c|}{ Variable } & Code & source & Type \\
\hline \multirow{19}{*}{ Climate } & & = Annual Mean Temperature & Biol & \multirow{19}{*}{ Worldclim } & \multirow{19}{*}{ continuous } \\
\hline & \multicolumn{2}{|r|}{$\begin{array}{l}\text { Bio } 2=\text { Mean Diurnal Range (Mean of monthly (max temp } \\
- \text { min temp)) }\end{array}$} & Bio2 & & \\
\hline & \multicolumn{2}{|c|}{ Bio 3 = Isothermality (P2/P7)*(100) } & Bio3 & & \\
\hline & \multicolumn{2}{|r|}{ Bio $4=$ Temperature Seasonality (standard deviation*100) } & Bio4 & & \\
\hline & \multicolumn{2}{|r|}{ Bio $5=$ Max Temperature of Warmest Month } & Bio5 & & \\
\hline & \multicolumn{2}{|c|}{ Bio $6=$ Min Temperature of Coldest Month } & Bio6 & & \\
\hline & \multicolumn{2}{|c|}{ Bio 7 =temperature Annual Range (P5-P6) } & Bio7 & & \\
\hline & \multicolumn{2}{|c|}{$\begin{array}{l}\text { Bio } 8=\text { Mean Temperature of Wettest Quarter } \\
\text { Bio } 9=\text { Mean Temperature of Driest Ouarter }\end{array}$} & Bio8 & & \\
\hline & \multicolumn{2}{|r|}{ Bio 9 =Mean Temperature of Driest Quarter } & Bio9 & & \\
\hline & \multicolumn{2}{|r|}{ Bio 10 =Mean Temperature of Warmest Quarter } & Biol0 & & \\
\hline & \multicolumn{2}{|r|}{ Bio 11 =Mean Temperature of Coldest Quarter } & Biol1 & & \\
\hline & \multicolumn{2}{|c|}{ Bio $12=$ Annual Precipitation } & Bio12 & & \\
\hline & \multicolumn{2}{|c|}{ Bio $13=$ Precipitation of Wettest Month } & Biol3 & & \\
\hline & \multicolumn{2}{|c|}{ Bio $14=$ Precipitation of Driest Month } & Biol4 & & \\
\hline & \multicolumn{2}{|r|}{$\begin{array}{l}\text { Bio } 15=\text { Precipitation of Seasonality (Coefficient of } \\
\text { Variation) }\end{array}$} & Biol5 & & \\
\hline & \multicolumn{2}{|c|}{ Bio 16 =Precipitation of Wettest Quarter } & Biol6 & & \\
\hline & \multicolumn{2}{|c|}{ Bio $17=$ Precipitation of Driest Quarter } & Biol7 & & \\
\hline & \multicolumn{2}{|c|}{ Bio $18=$ Precipitation of Warmest Quarter } & Biol8 & & \\
\hline & \multicolumn{2}{|c|}{ Bio $19=$ =Precipitation of Coldest Quarter } & Bio19 & & \\
\hline \multicolumn{3}{|c|}{ Elevation $(\mathbf{m})$} & elevation & $\begin{array}{l}\text { CARTOSAT } \\
\text { DEM }\end{array}$ & continuous \\
\hline \multicolumn{3}{|c|}{$\begin{array}{l}\text { Slope }\left({ }^{0}\right) \\
\text { Aspect }\left({ }^{0}\right)\end{array}$} & $\begin{array}{l}\text { Slope } \\
\text { Aspect }\end{array}$ & $\begin{array}{l}\text { Calculated } \\
\text { from } \\
\text { CARTOSAT } \\
\text { DEM }\end{array}$ & continuous \\
\hline \multicolumn{3}{|c|}{$\begin{array}{l}\text { Distance to the nearest village/ } \\
\text { tribal settlement }(\mathrm{m})\end{array}$} & $D 2 v$ & $\begin{array}{l}\text { Field data GPS } \\
\text { location }\end{array}$ & continuous \\
\hline \multicolumn{3}{|c|}{ Distance to the nearest water source (m) } & $D 2 d$ & SOI-toposheet & continuous \\
\hline \multicolumn{3}{|c|}{ Distance to the nearest watch station (m) } & $D 2 w t$ & $\begin{array}{l}\text { Field data GPS } \\
\text { location }\end{array}$ & continuous \\
\hline Distanc & o the & nearest road (m) & $D 2 r$ & SOI-toposheet & continuous \\
\hline Actual 1 & apo- & anspiration & $A E T$ & CGIR & continuous \\
\hline Aridity & & & AI Index & CGIR & continuous \\
\hline Populat & i der & & $\begin{array}{l}\text { Population } \\
\text { density }\end{array}$ & Diva GIS & continuous \\
\hline & & $1=$ Very Dense Forest & & & \\
\hline & & $2=$ Moderately Dense Forest & & & \\
\hline Forest & ver & $3=$ Open Forest & $f c m$ & Cattlitite dat & categorical \\
\hline Ty & & $4=$ Scrub & Jcm & Satemine data & \\
\hline & & $5=$ Water & & & \\
\hline & & $6=$ Non Forest & & & \\
\hline & & 1=Tropical Moist Deciduous & & & \\
\hline & & 2=Dry Deciduous & $f t m$ & Satellite data & \\
\hline Forest 7 & & $3=$ Northern Sub-Tropical Broadleaved & $J l m$ & Salemite data & categorical \\
\hline & & 4=Himalayan Temperate Forest & & & \\
\hline
\end{tabular}

\subsection{Fire modelling}

MaxEnt software package (version 3.3.3.e; Phillips et al., 2004; http:// www.cs.princeton.edu/ schapire/maxent/) was used for fire modeling that implements a maximum entropy algorithm, which generates a probability distribution map of similar conditions across the landscape considering the characteristics of the occurrence GPS locations (Phillips et al., 2006; Elith et al., 2011). The Maxent is a machine learning algorithm used to predict robust ecological niches of a species, with presence 
records, even when only a few are available (Elith et al., 2006; Phillips et al., 2006; Papeş and Gaubert, 2007; Kumar and Stohlgren, 2009). This model has an advantage where presence/available data are limited (Elith et al., 2006; Phillips and Dudik, 2008). In the present study based on the assumptions of the MaxEnt model a fire prediction modeling was attempted (Phillips et al., 2006).

\subsection{Model parameter settings}

The maximum number of background points was 5,000 and implementing linear, quadratic and hinge features was used (Phillips and Dudik 2008). 100 replicates were kept for model building (Flory et al., 2012) and the occurrence locations were partitioned randomly into two sub samples, using $75 \%$ of the locations as the training dataset and the remaining $25 \%$ for testing the resulting (partitioned) models. The accuracy of the model was using the area under the curve (AUC) of a receiver operating characteristic $(\mathrm{ROC})$ plot (ranging from $0.5=$ random to $1=$ perfect discrimination). Jackknife procedure was adopted to assess the variables importance (Yang et al., 2013). Average of 100 model predictions were used to produce a probability map of fire occurrence. However the other settings for the model parameters and values were kept as default.

Additionally, for demonstration of very highly, highly, moderately and least susceptible fire areas, all values above 0.8 were categorized as very highly susceptible to fire, the values between 0.6 and 0.8 as highly susceptible fire area and those between 0.2 and 0.4 as moderately susceptible fire areas. Based on a $10 \%$ training presence logistic threshold, values below 0.2 were selected as least susceptible fire area.

\section{Results and discussion}

A total of 529 fire incidences were found to be saptio-temporally independent. Multi-collinearity test showed that out of 31 variables only 22 variables were not correlated wth each other. Jackknife test results showed that based on the percentage contribution, "Forest canopy density" (18.2\%), "distance from nearest village" (d2v) (15\%), "Isothermality" (bio3) (12.4\%) and "Forest Type" $(10.1 \%)$ were the highest contributors. Based on permutation importance, "Precipitation of seasonality" (bio15) was the most significant variable (16.6\%) followed by "Isothermality" (bio3) (15.5\%) (figure 2).

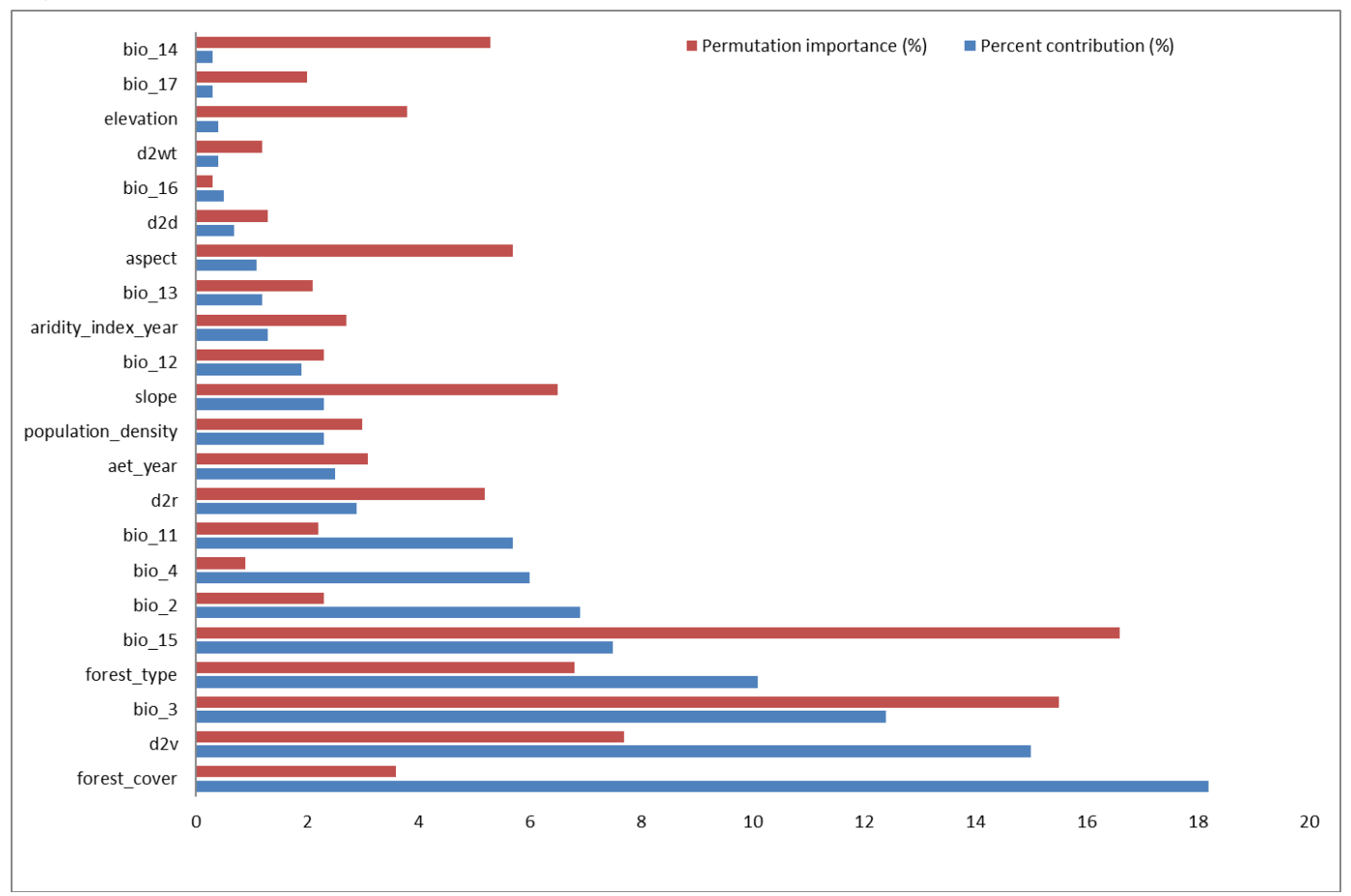

Figure 2 - Percent contribution and permutation importance of variables 
The area under the curve (AUC) score was 0.896 for the training data from our model, which indicates moderate to excellent predictive ability of the model (figure 3 ).

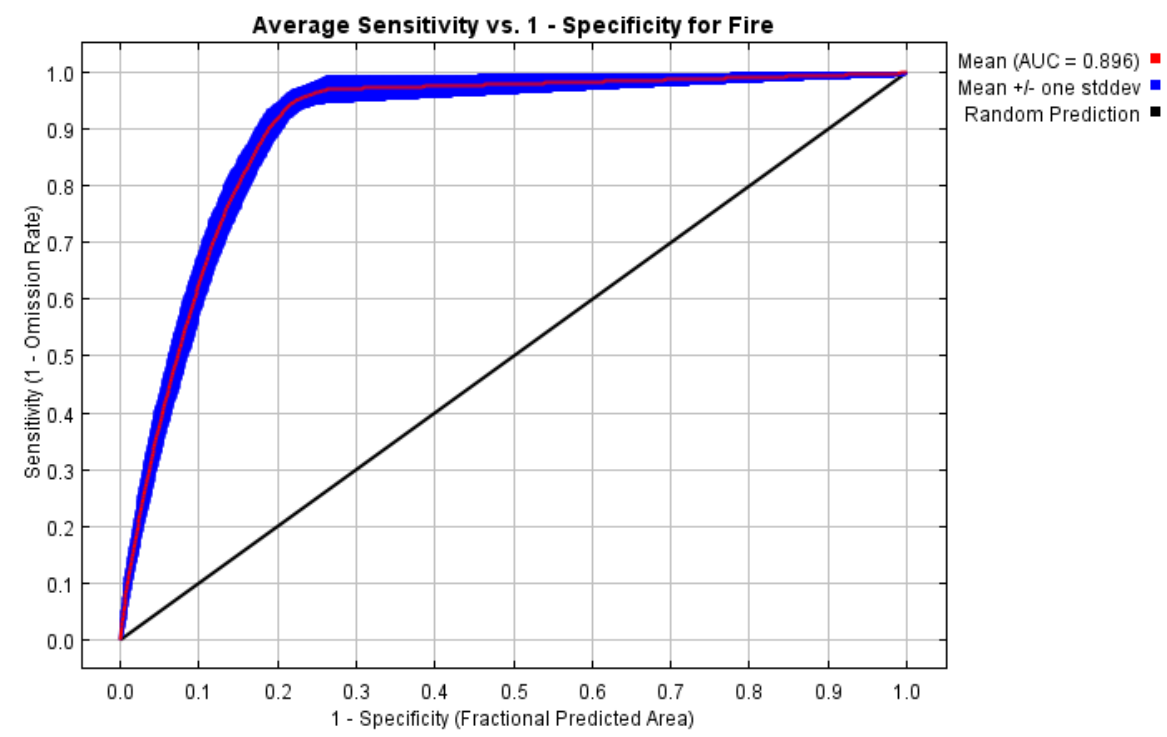

Figure 3 - Area under Curve of Fire (AUC)

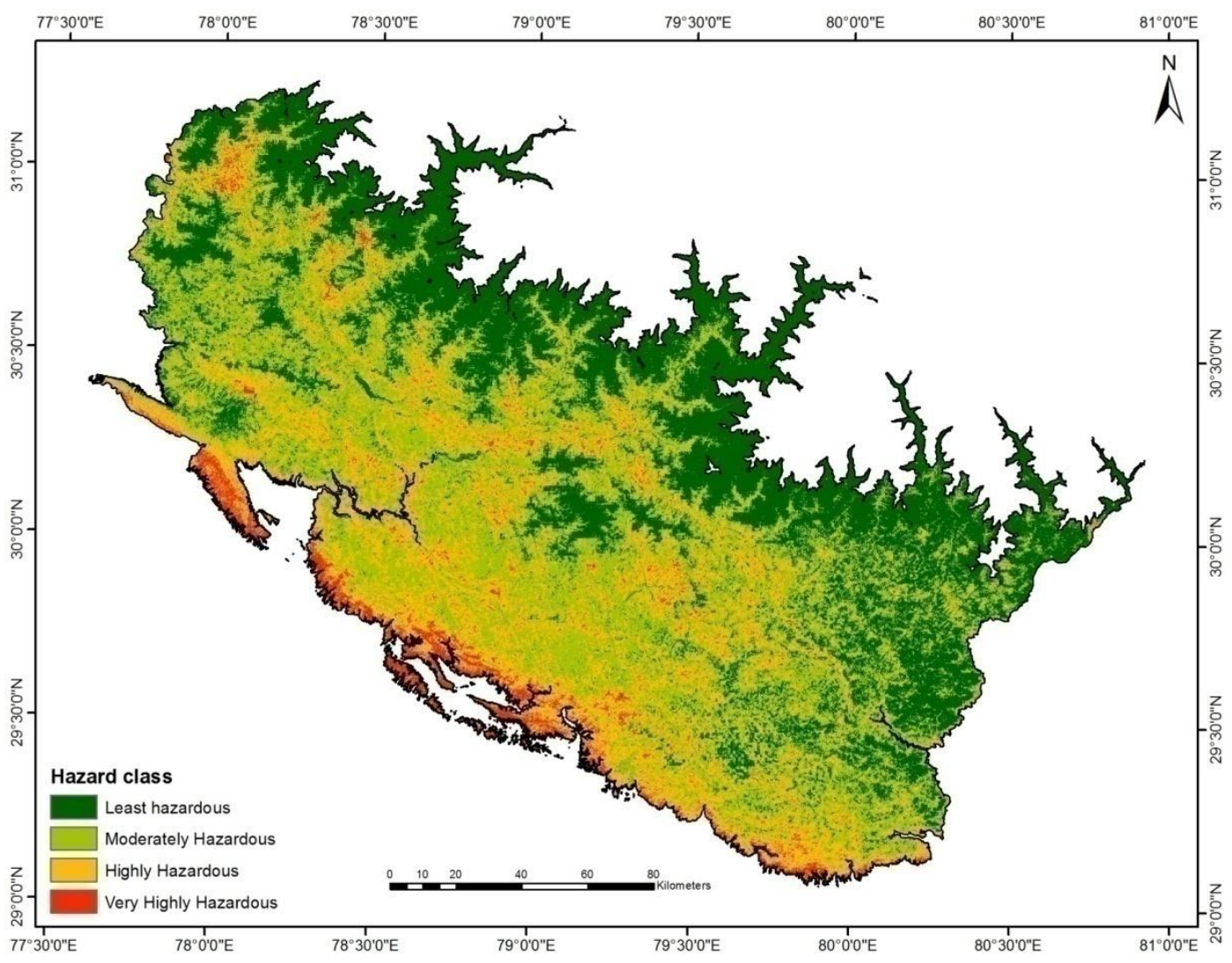

Figure 4 - Classified fire hazard map

The classified fire prediction map showed good discrimination between very high, high, moderate and least susceptible categories. The result demonstrated that out of the total geographical area of pine zone 120933.16 ha area $(3.64 \%)$ was under very high susceptible category, 708722.55 ha area $(21.39 \%)$ under high susceptible category, 1318959.84 ha area $(39.81 \%)$ under moderately susceptible 
category and 1164751.26 ha area (35.16\%) under least susceptible category (figure 4$)$. The areas near to village having moderate canopy density were highly affected by fire.

\section{Conclusion}

Pine forests at lower elevation and near to settlement are badly impacted by fire. The present methodology provides substantial improvement over frequency analysis method as used by earlier workers for developing fire hazard models in pine zone. Such types of models if recalibrated using future data can lead to higher degree of accuracy of fire prediction. Validation of fire hazard map shows that it resembles the ground situation, hence it can act as a baseline map for planning fire control in pine zone and can be useful for finalising best locations for fire lines, establishment of new Fire Crew Stations, Forest Guard Chowkis etc. GIS based modelling is helpful in identifying, mapping, quantification of biophysical parameters at spatio-temporal scale and also for the future predictions of forest fire. Geospatial modelling can potentially enhance forest fire management by providing spatially mapped fire hotspots. The forest fire hazard model as generated under this study would be helpful in detecting and mitigating the fire in pine zone of Himalayas and can be used for preparatory planning to minimize the fire frequency and losses thereof. Our results showed that MaxEnt may become an important tool to guide on-the-ground decisions on fire prevention actions and planning more effectively for management of forest fire with respect to conservation of forest and biodiversity in Pine Zone.

\section{References}

Craw. (1875). A few notes on the nursery treatment of Chil, Chir. Indian Forester,(1), 305.

Dhaundiyal, A. and Gupta, V. K. (2014). The analysis of pine needles as a substrate for gasification. Hydro Nepal: Journal of Water, Energy and Environment; 15, 73-81.

Elith, J, Phillips, S.J, Hastie, T, Dudík, M, Chee, Y.E., Yates, C.J. (2011). A Statistical Explanation of MaxEnt for Ecologists. Diver. and Distri. 17, 43-57

Elith, J, Graham, C.H., Anderson, R.P., Dudík, M., Ferrier, S., Guisan, A., Hijmans, R.J., Huettmann, F., Leathwick, J.R., Lehmann, A., Li J., Lohmann, L.G., Loiselle, B.A., Manion, G., Moritz, C., Nakamura, M., Nakazawa, Y., Overton, J.M., Peterson, A.T., Phillips, S.J., Richardson, K.S., Scachetti-Pereira, R., Schapire, R.E., Soberón, J., Williams, S., Wisz, M.S., Zimmermann, N.E., (2006). Novel methods improve prediction of species' distributions from occurrence data. Ecography, 29, 129-151.

Flory, A.R., Kumar, S., Stohlgren, T.J., Cryan, P.M. (2012). Environmental conditions associated with bat white nose syndrome mortality in the north-eastern United States. J Appl Ecol, 49: 680-689.

Forest Survey of India. (2013). India State of Forest Report. MOEF, Govt. of India.

Gamble, J. S. (1875). The Darjeeling Forests. Indian Forester (1) 81.

Hijmans, R. J. et al; (2002) DIVA-GIS Version 2, A geographic information system for the analysis of biodiversity data Manual.

Hijmans, R. J., Cameron SE, Parra JL, Jones PG, Jarvis, A. (2005). Very high resolution interpolated climate surfaces for global land areas. Int. J. Clim. 25, 1965-1978.

Kumar, S, Stohlgren, T.J. (2009).Maxent modeling for predicting suitable habitat for threatened and endangered tree Canacomyrica monticola in New Caledonia. J. Ecol. and Nat. Envir. 1(4), 94-98

Phillips, S. J. et al., (2006).Maximum entropy modelling of species geographic distributions.

Phillips, S. J., Miroslav, D, Schapire, R.E. (2004). Maxent Software for Species Distribution Modeling. http://cs.princeton.edu/ schapire/Maxent/ 
Phillips, S. J., Anderson, R.P, Schapire, R.E. (2006). Maximum entropy modeling of species geographic distributions. Ecol Mod, 190: 231-259

Pearson, R., Raxworthy C, Nakamura M, Peterson, A. (2007). Predicting species distributions from small numbers of occurrence records: a test case using cryptic geckos in Madagascar. $J$ Biogeo, 34:102-117.

Phillips, S. J., Dudík, M (2008). Modeling of species distributions with Maxent: new extensions and a comprehensive evaluation. Eco gra, 31: 161-175

Troup, R.S. (1921). The Silviculture of Indian Trees. Vol. III. Clarendon Press, Oxford, UK.

Verma, A. K., and Kumar,S. (2015). Mapping Fire Hazard in Rajaji National Park, Future Perspective of Wildlife Habitat Conservation by Using Remote Sensing and GIS. International Journal of Technical Research and Applications. 5(3), 81-88. ISSN: 2320-8163.

Verma, A.K., Singh, D., Sharma, S.D. and Khanduri, K. (2013). Forest Fire Risk Zonation in Raipur Range, Mussoorie Forest Division using: GIS and Remote Sensing Technology. International Journal of Advanced Scientific and Technical Research, 6(3), 141-150. ISSN 2249-9954

Verma, A.K. (2016). Predictive modeling and mapping of wildland fire in Lansdowne corridor of Lesser Himalayas: A future perspective for Tiger conservation. In: Proceedings for the $5^{\text {th }}$ International Fire Behavior and Fuels Conference, International Association of Wildland fire, Missoula, Montana, USA.

Warren, D.L., R.E., Glor, R.E., Turelli, M (2010). ENM Tools: a toolbox for comparative studies of environmental niche models. Ecogr, 33:607-611

Yang, X., Kushwaha, S. P. S., Saran, S., Xu, J., Roy, P.S. (2013). MaxEnt modeling for predicting the potential distribution of medicinal plant, Justicia adhatoda L. in Lesser Himalayan foothills, Ecological Eng, 51, 83- 87.

\section{Websites:}

http://sbb.uk.gov.in/pages/display/93-about-uttarakhand http://www.worldclim.org/bioclim https://firms.modaps.eosdis.nasa.gov 